That Leeds, as a busy and successful museum official, did not neglect the claims of scholarship is shown by the many excavations on local sites which he undertook (notably those of the Neolithic causeway and settlement at Abingdon, Berks, the Iron Age camps at Chastleton, Oxon, and Chun Castle, Cornwall, and of the Anglo-Saxon village at Sutton Courtenay, Berks) and by the list of six books and more than ninety smaller papers which appear in the bibliography of his writings in the forthcoming volume of essays entitled "Dark-Age Britain" offered to hirn by a group of his friends and pupils. His chief work lay in Anglo-Saxon studies. His book, "The Archæology of the Anglo-Saxon Settlements", published in 1913, can fitly claim to have been epoch making, as it laid the foundation of all the more recent work on the subject, and showed, once for all, how great a contribution archæology could make to a study which had previously seemed to be almost solely the prerogative of the historian. He followed this with two more books and numerous papers, which showed how, though his views may have been modified in detail as the years passed, his main arguments stood firm in his own mind and have, indeed, now won general acceptance. Besides his work for Anglo-Saxon studies, Leeds also made major contributions to scholarship in several other fields, notably with his book "Celtic Ornament" (1933), and with his work on numismatics (Roman and Chinese) and his several papers connected with Oxford inns and traders.

Leeds was Fellow, and later honorary Fellow, of Brasenose College, Oxford, and was also elected this year to an honorary fellowship of Magdalene College, Cambridge, where he had been an undergraduate. He was a Fellow of the Society of Antiquaries and a vice-president during 1929-32, and an honorary associate of the Royal Institute of British Architects.

D. B. HARDEN

\section{Prof. Haakon Shetelig}

HaAkon Shetelig, formerly director of the Bergen Museum and professor of archæology there, who died on July 23 at the age of seventy-eight, was a distinguished authority on Scandinavian prehistory and on the archæology of the Vikings. He was particularly well known in Britain, both for tho admirable account in his "Scandinavian Archrology" (Oxford, 1937), written in conjunction with the philologist Hjalmar Falk, and for his interest in the archæological traces of the Vikings in the British Isles, of which he left a permanent memorial in the six parts of "Viking Antiquitios in Great Britain and Treland", published in 1940 (pts. I-IV) and 1954 (pt. VI) on behalf of the Norwegian Scientific Research Fund of 1919. Much of the writing was contributed by British and Norwegian scholars, but Shetelig edited the whole work and himself contributed a masterly introduction to the history of the Vikings in Western Europe.

Shetelig was a genial and hospitable as well as a learned man, and he had an abiding love and respect for Britain. He had a particularly warm place in his heart for the amateur scholar, whom he regarded as the fine flower of our society in the days of its prime. It must have given him peculiar pleasure to be awarded the Gold Medal of the Society of Antiquaries of London, a recognition which came to him in 1939 .

Grahame Clark

\author{
Dr. C. H. N. Jackson, O.B.E.
}

DR. C. H. N. JACKson, chief entomologist of the East African Tsetse Research Organization, died in hospital in England on July 28. His whole career was devoted to research in East Africa, his first appointment being in 1927 as zoologist to the Department of Game Preservation in Tanganyika. C. F. M. Swynnerton was the head of the Department, and Jackson was one of the team of able young men who Swynnerton inspired to work on the tsetse fly which then, as now, was one of the major problems of East Africa. Swynnerton persuaded his Government and the Colonial Office to set up a separate Department of Tsetse Research, and Jackson was appointed as survey entomologist to it in 1932. $\mathrm{He}$ became senior entomologist in 1936. In 1948 tsetse research became the responsibility of the East African High Commission, and Jackson was appointed research officer in the Tsetse Research Organization, becoming chief entomologist in 1951. He held the degree of D.Sc. of the University of London, and was appointed O.B.E. in the Queen's Birthday Honours List this year.

Jackson was, like Swynnerton, an excellent fieldworker, and spent much of his time almost com. pletely isolated from the amenities of civilization and even from his colleagues. His work, carried out over so many years at Kakoma in Central Tanganyika under difficult and uncomfortable conditions, provides data on the tsetse of continuing value to all concerned with similar problerns. But Jackson was not only a field-worker; he combined this with rigorous academic standards, and an ability to keep up to date with theoretical and laboratory work in his own and allied subjects. He will be particularly remem. bered for his work on natural populations. This applied primarily to the tsetse fly, but is accepted by others as applying much more generally to other ecological problems. A particular contribution was his development of the 'marking' technique, by which tsetse flies were marked with spots of paint in such a way that the date and place of release could be indicated and recaptures could also be recorded. He spent much of his leave analysing his data, and was among the first field-workers to apply the methods of Sir Ronald Fisher to his results. He had a real enthusiasm for his subject which he communicated to those who discussed his work with him either in the laboratory in Britain or in the field in East Africa. His work, though individual, was also part of the work of a team of scientists who have done much to make tsetse control over large areas a possibility.

KenNeTh MELLANBY

\section{Mr. R. L. Collett, M.B.E.}

Ronald Leslie Colrets, who died on August 15, will be remembered for the devoted service he gave to the profession of chemistry as assistant secretary (1925-44) and as registrar (1945-51) of the Institute of Chemistry of Great Britain and Ireland, now the Royal Institute of Chemistry. Throughout that period he was always available for consultation by students and members of the Institute on matters affecting their careers, and there were few who at some time or other did not benefit from his advice and help in resolving professional or personal difficulties. Even those who at first were overawed by the luxuriance of his eyebrows or his somewhat didactic manner soon came to regard him as a 